\title{
Effect of Slag Composition on Non-metallic Inclusions for Gear Steel during LF Process \\ Wei LIN
}

CISDI Engineering Co., Ltd.

NO.1, Saidi Road, Jinyu Avenue, Yubei District 401122, Chongqing, China

*wei.a.lin@cisdi.com.cn

Keywords: Gear steel, LF, CaO- $\mathrm{Al}_{2} \mathrm{O}_{3}-\mathrm{MgO}$ slag, Non-metallic inclusions.

\begin{abstract}
Effect of slag composition on non-metallic inclusions for gear steel during LF process is investigated in this paper. It is found that with $\mathrm{CaO}-\mathrm{Al}_{2} \mathrm{O}_{3}-\mathrm{MgO}$ slag and low $\mathrm{SiO}_{2}$ content in the slag, non-metallic inclusions in liguid steel can be transformed into tiny globular $\mathrm{CaO}-\mathrm{MgO}-\mathrm{Al}_{2} \mathrm{O}_{3^{-}}$ CaS complex inclusions during LF refining process, which is helpful to improve the quality of gear steel.
\end{abstract}

\section{Introduction}

Non-metallic inclusions in steel have great influence on fatigue performance of high strength gear steel. The larger, distortion-free, irregular and angular shaped inclusions may actually be more harmful for fatigue performance of steel[1]. After LF refining treatment, most of non-metallic inclusions in liquid steel are transformed into tiny globular inclusions, which is helpful to improve the quality of steel[2]. The different types of LF refining slag will transform non-metallic inclusions differently, so how to choose the refining slag is very important.

\section{LF Refining Slag}

The general smelting process of gear steel is that charging SiMn ferroalloy when BOF tapping and feeding $\mathrm{Al}$ line in $\mathrm{LF}$ refining process for deoxidization. $\mathrm{LF}$ refining slag is $\mathrm{CaO}-\mathrm{SiO}_{2}-\mathrm{Al}_{2} \mathrm{O}_{3}$ slag $\left(\mathrm{Al}_{2} \mathrm{O}_{3} \sim 15 \%\right)$. New smelting process for gear steel in this paper is that charging $\mathrm{Al}$ for deoxidization directly, $\mathrm{LF}$ refining slag is $\mathrm{CaO}-\mathrm{Al}_{2} \mathrm{O}_{3}-\mathrm{MgO}$ slag with less $\mathrm{SiO}_{2}$ content. The alkalinity $\mathrm{CaO} / \mathrm{Al}_{2} \mathrm{O}_{3}$ is between 1.4 to 3.2 .

The two kinds of slag composition listed above is used in this paper, and steel samples is taken at early stage (15 minutes after charging deoxidizer) and the end of LF refining process. Steel samples were polished and the chemical composition and profile of inclusions in steel samples were analyzed by SEM-EDS.

\section{The Transformation of Non-metallic Inclusions during LF Treatment}

The $\mathrm{CaO}-\mathrm{SiO}_{2}-\mathrm{Al}_{2} \mathrm{O}_{3}$ slag has been adopted in the LF treatment, and fig.1 shows the non-metallic inclusions of steel samples which were taken at early stage of LF refining process. 


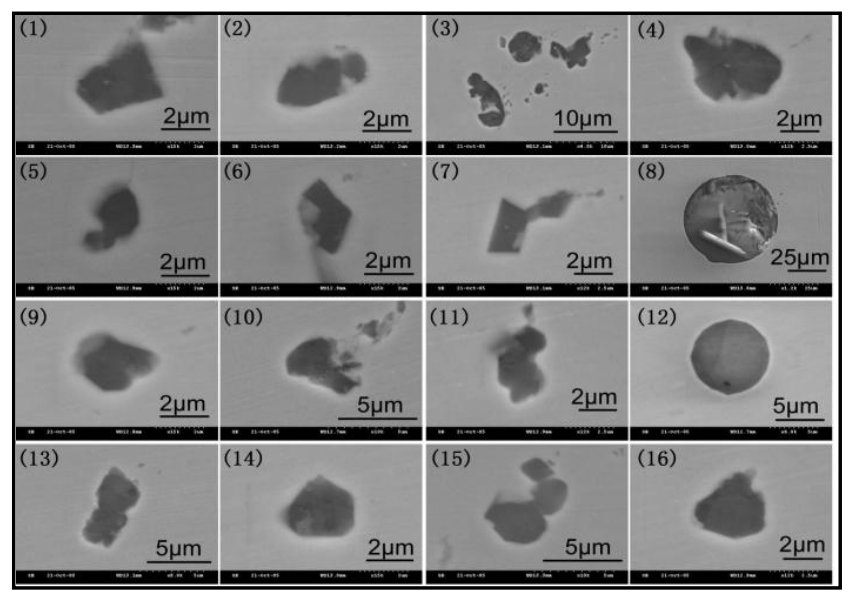

Fig.1. Non-metallic inclusions of steel samples with $\mathrm{CaO}-\mathrm{SiO}_{2}-\mathrm{Al}_{2} \mathrm{O}_{3}$ slag

It is shown by Fig. 1 that the size of inclusions is mostly smaller than $10 \mu \mathrm{m}$ at early stage of LF refining process. It is found by SEM-EDS that the inclusions consist of $\mathrm{MgO}-\mathrm{Al}_{2} \mathrm{O}_{3}$ and part of them are circular calcium aluminate inclusions. Minority of the inclusions contain a few $\mathrm{SiO}_{2}$.

The fig. 2 shows the non-metallic inclusions of steel samples which were taken at early stage of the $\mathrm{LF}$ refining process when adopting the $\mathrm{CaO}-\mathrm{Al}_{2} \mathrm{O}_{3}-\mathrm{MgO}$ slag. It is shown that the size of inclusions is mostly smaller than $10 \mu \mathrm{m}$ after high basicity slag washing, strong deoxidizing and argon bubbling process. It is found by SEM-EDS that the inclusions mainly consist of $\mathrm{Al}_{2} \mathrm{O}_{3}$ and part of them contain $\mathrm{Cr}_{2} \mathrm{O}_{3}$ and $\mathrm{MnS}$.

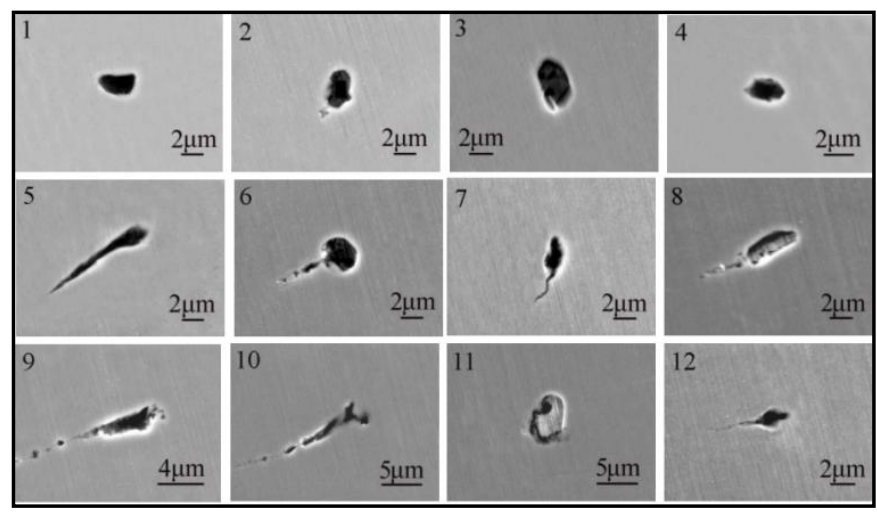

Fig.2. Non-metallic inclusions of steel samples adopting the $\mathrm{CaO}-\mathrm{Al}_{2} \mathrm{O}_{3}-\mathrm{MgO}$ slag

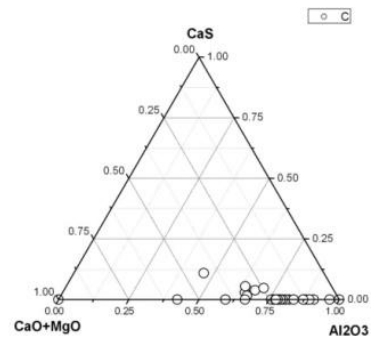

(a)Inclusion Component with $\mathrm{CaO}-\mathrm{SiO}_{2}-\mathrm{Al}_{2} \mathrm{O}_{3}$ slag

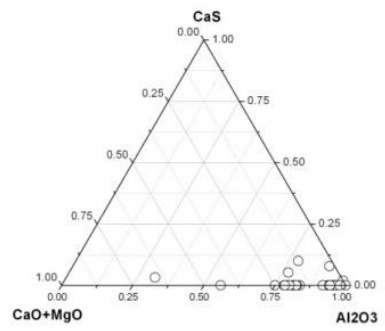

(b) Inclusion Component with $\mathrm{CaO}-\mathrm{Al}_{2} \mathrm{O}_{3}-\mathrm{MgO}$ slag

Fig.3. Comparison of Inclusion Component with different slag at early stage of LF treatment

The gear steel smelting experiments show that the floating degree of the inclusions in the liquid steel adopting the $\mathrm{CaO}-\mathrm{Al}_{2} \mathrm{O}_{3}-\mathrm{MgO}$ slag is obviously higher than that in the liquid steel adopting the $\mathrm{CaO}-\mathrm{SiO}_{2}-\mathrm{Al}_{2} \mathrm{O}_{3}$ slag at early stage of $\mathrm{LF}$ refining process in fig.3. At that time, most of the deoxidation products $\mathrm{Al}_{2} \mathrm{O}_{3}$ transform into $\mathrm{MgO} \cdot \mathrm{Al}_{2} \mathrm{O}_{3}$ inclusions. Due to the short reaction time 
between liquid steel and slag, $\mathrm{CaO}$ in the slag is not reduced. As a result of this, the inclusions contained a few $\mathrm{CaO}$. Despite adopting the high basicity slag washing and argon bubbling process, $\mathrm{Al}_{2} \mathrm{O}_{3}$ inclusions in liquid steel have not been transformed into calcium aluminate inclusions .

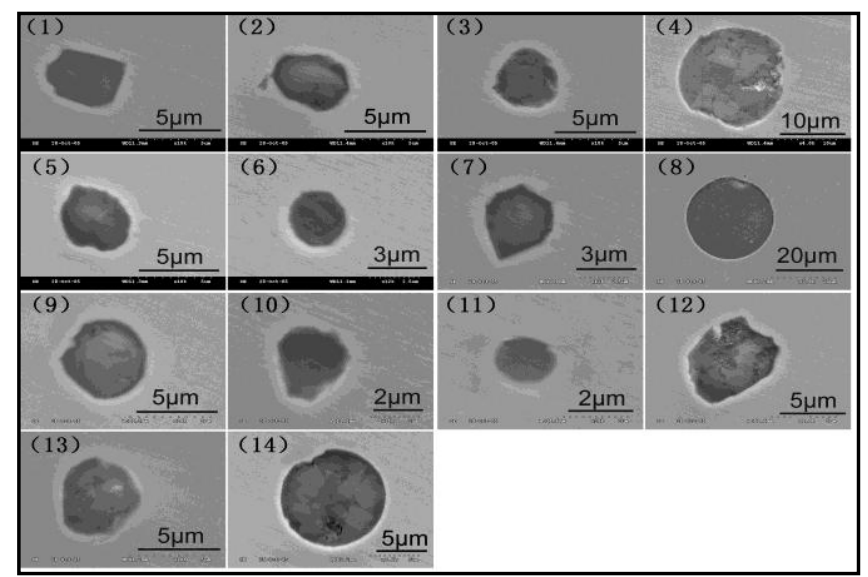

Fig.4. Non-metallic inclusions of steel samples with $\mathrm{CaO}-\mathrm{SiO}_{2}-\mathrm{Al}_{2} \mathrm{O}_{3}$ slag at the end of $\mathrm{LF}$ process

Fig.4 shows the inclusions in the liquid steel adopting $\mathrm{CaO}-\mathrm{SiO}_{2}-\mathrm{Al}_{2} \mathrm{O}_{3}$ slag at the end of $\mathrm{LF}$ process. With the SEM-EDS analysis, it is found that there are three types of inclusions: (1) MgO$\mathrm{Al}_{2} \mathrm{O}_{3}$ complex inclusion; (2) $\mathrm{CaO}-\mathrm{Al}_{2} \mathrm{O}_{3}-\mathrm{MgO}$ complex inclusion; (3) A few $\mathrm{MnO}-\mathrm{Cr}_{2} \mathrm{O}_{3}$ and $\mathrm{MnS}$ complex inclusion.

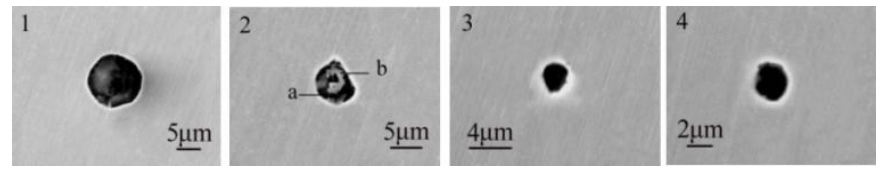

Fig.5. Non-metallic inclusions of steel samples adopting the $\mathrm{CaO}-\mathrm{Al}_{2} \mathrm{O}_{3}-\mathrm{MgO}$ slag at the end of $\mathrm{LF}$ process

Fig.5 showed the inclusions in the liquid steel adopting $\mathrm{CaO}-\mathrm{Al}_{2} \mathrm{O}_{3}-\mathrm{MgO}$ slag at the end of $\mathrm{LF}$ process. With the SEM-EDS analysis, it is found that non-metallic inclusions of liquid steel mostly are transformed into tiny globular calcium aluminate and magnesium aluminate complex inclusions after LF refining process, part of which contain a few $\mathrm{CaS}$.

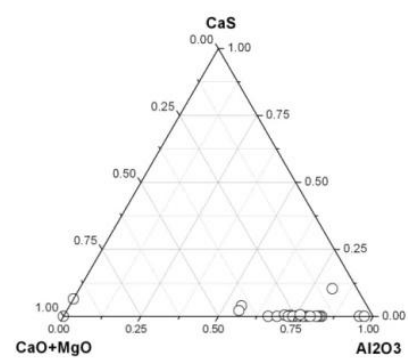

(a) $\mathrm{CaO}-\mathrm{SiO}_{2}-\mathrm{Al}_{2} \mathrm{O}_{3}$ slag

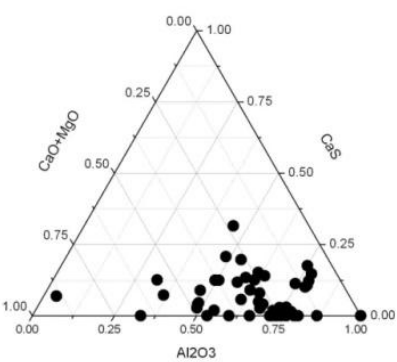

(b) $\mathrm{CaO}-\mathrm{Al}_{2} \mathrm{O}_{3}-\mathrm{MgO}$ slag

Fig.6. Comparison of Inclusion Components with different slag at the end of LF treatment

The gear steel smelting experiments show that $\mathrm{CaO}$ and $\mathrm{CaS}$ occupy a bigger proportion in the inclusion of liquid steel adopting $\mathrm{CaO}-\mathrm{Al}_{2} \mathrm{O}_{3}-\mathrm{MgO}$ slag than that in the liquid steel adopting $\mathrm{CaO}-$ $\mathrm{SiO}_{2}-\mathrm{Al}_{2} \mathrm{O}_{3}$ slag. After $\mathrm{LF}$ refining, $\mathrm{CaO}$ and $\mathrm{CaS}$ content in inclusions increase and is sphere shaped. The $\mathrm{CaO} / \mathrm{Al}_{2} \mathrm{O}_{3}$ rate of the calcium aluminate inclusions adopting $\mathrm{CaO}-\mathrm{Al}_{2} \mathrm{O}_{3}-\mathrm{MgO}$ slag gradually is close to 1 , which is located at the low-melting-point region of the $\mathrm{CaO}-\mathrm{Al}_{2} \mathrm{O}_{3}$ phase 
diagram[3], while the $\mathrm{CaO}$ content of the calcium aluminate inclusions adopting $\mathrm{CaO}-\mathrm{SiO}_{2}-\mathrm{Al}_{2} \mathrm{O}_{3}$ slag is around $30 \%$.

By $\mathrm{CaO}-\mathrm{Al}_{2} \mathrm{O}_{3}-\mathrm{MgO}$ slag, the inclusions in the liquid steel at early stage of LF refining composes of $\mathrm{Al}_{2} \mathrm{O}_{3}$ inclusions which will be transformed into $\mathrm{CaO}-\mathrm{MgO}-\mathrm{Al}_{2} \mathrm{O}_{3}$ inclusions by $\mathrm{LF}$ refining. At the end of LF refining process, most of inclusions have been transformed into tiny globular $\mathrm{CaO}-\mathrm{MgO}-\mathrm{Al}_{2} \mathrm{O}_{3}-\mathrm{CaS}$ complex inclusions which are helpful for the improvement of the quality of gear steel.

\section{Conclusions}

By comparison between two types of LF refining slag, conclusions are drawn as below.

1)At early stage of LF refining process, the floating degree of the inclusions in the liquid steel adopting $\mathrm{CaO}-\mathrm{Al}_{2} \mathrm{O}_{3}-\mathrm{MgO}$ slag is obviously higher than that in the liquid steel adopting $\mathrm{CaO}-\mathrm{SiO}_{2}-$ $\mathrm{Al}_{2} \mathrm{O}_{3}$ slag.

2) $\mathrm{CaO}$ and $\mathrm{CaS}$ occupy a bigger proportion in the inclusion of liquid steel adopting $\mathrm{CaO}-\mathrm{Al}_{2} \mathrm{O}_{3^{-}}$ $\mathrm{MgO}$ slag than that in the liquid steel adopting $\mathrm{CaO}-\mathrm{SiO}_{2}-\mathrm{Al}_{2} \mathrm{O}_{3}$ slag.

3)At the end of LF refining process, most of non-metallic inclusions have been transformed into tiny globular $\mathrm{CaO}-\mathrm{MgO}-\mathrm{Al}_{2} \mathrm{O}_{3}-\mathrm{CaS}$ composite inclusions which are helpful for the improvement of the quality of gear steel.

\section{References}

[1] M.D. Chapetti, T. Tagawa, T. Miyata, Ultra-long cycle fatigue of high-strength carbon steels part II: estimation of fatigue limit for failure from internal inclusion, Material Science and Engineering(2003), PP.236 244.

[2] Duckworth W E. and Ineson E., Clean steel. 77(Iron Steel Inst. 1963), PP.87.

[3] R. story, J. piccone ,Richard J. Fruehan et al. Inclusion Analysis to Predict Casting Behavior. Iron and Steel Technology[J]. Sep 2004:163 169. 